Acta Agroph., 2019, 26(3), 15-28

doi: $10.31545 /$ aagr/114016

\title{
THE EFFECT OF FERTILIZATION AND EFFECTIVE MICROORGANISMS ON BUCKWHEAT AND MILLET
}

\author{
Anna Jaroszewska®, Magdalena Sobolewska®, Cezary Podsiadto®, \\ Stawomir Stankowski iD \\ Department of Agroengineering, West Pomeranian University of Technology in Szczecin \\ Papieża Pawła VI 3, Szczecin, Poland \\ e-mail: anna.jaroszewska@zut.edu.pl
}

\begin{abstract}
A bstract. The experiment was conducted in 2016 and 2017 in the vegetation hall of the Faculty of Environmental and Agricultural Development, West Pomeranian University of Technology in Szczecin. The main goal of the study was to assess the influence of the biological preparation of effective microorganisms (EM), mineral and natural fertilization on: the yield of buckwheat (Fagopyrum Mill.) and millet (Panicum miliaceum L.), the SPAD index (leaf greenness index), the content of macro- and microelements in grain $(\mathrm{N}, \mathrm{P}, \mathrm{K}, \mathrm{Ca}, \mathrm{Mg}, \mathrm{Na}, \mathrm{Cu}, \mathrm{Mn}, \mathrm{Mo}, \mathrm{Fe}$ and $\mathrm{Zn}), \mathrm{pH}_{\mathrm{KCl}}$, the content of organic $\mathrm{C}\left(\mathrm{C}_{\text {org }}\right)$, macro- and microelements (N, $\mathrm{P}, \mathrm{K}, \mathrm{Ca}, \mathrm{Mg}, \mathrm{Cu}, \mathrm{Mn}, \mathrm{Fe}$ and $\mathrm{Zn}$ ) in soil. Both of the species studied responded with a significantly higher yield due to natural fertilization. The positive role of the EM used should be emphasized, especially in relation to the soil. In buckwheat and millet plots, in which EM were applied, there was an upward trend in the concentration of the investigated macronutrients in the soil. The experiment conducted shows that microbiological preparations can improve the chemical properties of the soil, and the nature of their activity may depend on their type, dose, the species of the plant, the stage of development during which it is applied, and the climate and soil conditions.

Ke y w ords: effective microorganisms, grain, manure, mineral compounds, mineral fertilization, soil
\end{abstract}

\section{INTRODUCTION}

New possibilities of enriching and diversifying food production, especially of plant origin, are still being sought, which is a result of, among other factors, a significant narrowing in the crop species number. The intensification of agriculture, and thus the cultivation of the most productive plants with minimal agrotechnical requirements, has contributed to the overproduction of certain plant species, as well as the impoverishment and contamination of soils, and thus the degradation of the natural environment, lowering food quality, and as a consequence, contributing to the spread of diseases of civilization (Aktar et al. 2009). Two species of 
cultivated plants, which are attracting increasing interest, mainly due to the significant possibilities of using them in the production of pro-health food are buckwheat (Fagopyrum Mill.) and millet (Panicum miliaceum L.). Buckwheat is a product recommended in the diet for the purposes of prophylaxis and diet therapy in the treatment of many diseases of civilization. Substances contained in buckwheat have a positive effect on the functioning of the human body. In comparison with other cereals, it is more abundant in essential amino acids, minerals and B vitamins (Linh et al. 2014). Millet, like buckwheat, is a gluten-free cereal, and therefore it can be consumed by people with celiac disease and gluten intolerance. It is also a great source of B vitamins and beneficial polyunsaturated fatty acids and antioxidants.

In association with environmental improvement, interest in proecological plant growing technologies aims to replace traditional methods with biological methods, the purpose of which is to enhance soil fertility by increasing its microbiological activity, thereby improving both the physical and chemical properties of the soil, and ultimately increasing both the crop yield and quality (Yamada and Xu 2001). The global trend seems to be a shift towards reducing the use of chemicals in the cultivation of plants, and thus the use of safer and greener alternatives. For production that does not threaten the natural environment, chemical plant protection products or mineral fertilizers can be replaced with natural fertilizers such as manure and liquid manure, as well as with organic fertilizers. In the opinion of Babaeian et al. (2011), the use of inorganic chemical fertilizers is hazardous to the soil environment. These materials cause problems not only in the area of soil health, but also to human health and the physical environment. Also, chemical fertilizers consume a large amount of energy and money (Khan et al. 2013). The positive effect of organic fertilization on the growth and yields of plants was confirmed by Okoroafor et al. (2013). An improvement of soil properties and crop productivity was reported by Mahmood et al. (2017). According to some scientists (Kaczmarek et al. 2007), a role similar to that of fertilizers can also be performed by biological preparations, which include effective microorganisms (EM) or mycorrhizal preparations, especially since previous studies have shown (Khaliq et al. 2006) the competitiveness of their application in relation to traditional solutions. The controlled use of rhizosphere bacteria, especially in organic crops, may, the opinion of according to Dąbrowska and Zdziechowska's (2015), potentially contribute to reducing the use of artificial mineral fertilizers and herbicides.

The usefulness of the crop for further use as a food depends on the interaction of several factors. The composition of plants may be modified by many factors: genetic features, protection against pests, climatic conditions, soil conditions and the closely related factor of fertilization. Grain yields are not a simple fertilizing function. Both deficiencies and an excess of minerals are very unfavourable to plants. The use of rational fertilization, based on a comprehensive analysis of soil and leaves, determines the outcome of a high-quality yield and lower production 
costs. Nitrogen $(\mathrm{N})$ is the most important limiting factor, followed by water deficit, for biomass production in natural ecosystems. An insufficient dose of $\mathrm{N}$ may cause a reduction in the leaf surface, chlorophyll content, as well as a reduction in photosynthetic activity or plant biomass. On the other hand, an excessive use of $\mathrm{N}$ fertilizers causes lodging and diseases, an increase in production costs, the pollution of groundwater and it also frequently results in a decrease in yields (Yang et al. 2014a). A rapid and reliable assessment of crop nutritional status in terms of $\mathrm{N}$ during vegetation is an important element in the application of this macronutrient with fertilizer. The current nutritional status of plants with $\mathrm{N}$ is obtained by measuring the content of chlorophyll with the use of a chlorophyll-meter on the basis of the leaf greenness index (SPAD index). Evaluation of the chlorophyll content in the plant is also a good indicator of water stress in plants. Water deficiency affects the reduction of chlorophyll concentration in the leaves of plants.

Therefore, the aim of the research was to determine the impact of effective microorganisms (EM), manure and mineral fertilization on the chemical composition of grain and soil and the leaf greenness index (SPAD index) in the cultivation of buckwheat (Fagopyrum Mill.) and millet (Panicum miliaceum L.).

\section{MATERIAL AND METHODS}

The plot experiment was carried out in 2016 and 2017 in the vegetation hall of the Faculty of Environmental and Agricultural Development, West Pomeranian University of Technology in Szczecin $\left(53^{\circ} 26^{\prime} 50^{\prime \prime} \mathrm{N}, 14^{\circ} 31^{\prime} 45^{\prime \prime} \mathrm{E}\right)$. The influence of the biological preparation of effective microorganisms (EM), mineral and natural fertilization on the following results was assessed: yield of buckwheat (Fagopyrum Mill.) and millet (Panicum miliaceum L.), SPAD index (leaf greenness index), content of macro- and microelements in grain (N, P, K, Ca, Mg, Na, Cu, Mn, Mo, Fe and $\mathrm{Zn}), \mathrm{pH}_{\mathrm{KCl}}$, content of organic $\mathrm{C}\left(\mathrm{C}_{\mathrm{org}}\right)$ as well as macro- and microelements $(\mathrm{N}$, $\mathrm{P}, \mathrm{K}, \mathrm{Ca}, \mathrm{Mg}, \mathrm{Cu}, \mathrm{Mn}, \mathrm{Fe}$ and $\mathrm{Zn}$ ) in soil.

The experiment involved (in doses compliant with agrotechnical recommendations): 1. EmFarma PlusTM product, which contained a properly selected composition of beneficial microorganisms, genetically non-modified microbial strains and their metabolites, contained in a fermented mixture of natural ingredients (http://www.probiotics.pl). The application was carried out by spraying the soil with the preparation ( $2.5 \mathrm{ml}$ of preparation / $35 \mathrm{ml}$ of water / per plot), which was mixed with the soil to enhance the effect. 2. Granulated bovine manure (150 g plot $\left.{ }^{-1}\right)$ containing (minimum): $\mathrm{N} 2.1, \mathrm{P}_{2} \mathrm{O}_{5} 1.6, \mathrm{~K}_{2} \mathrm{O} 5.9, \mathrm{Ca} 2.0, \mathrm{Mg} 0.5$ (\% DM), organic substance $-60 \%$ DM, humic substances $-25 \%$ DM. 3. Ammonium nitrate ( $4 \mathrm{~g} \mathrm{plot}^{-1}$ for buckwheat and $4 \mathrm{~g} \mathrm{plot}^{-1}$ for millet) containing $34 \% \mathrm{~N}$. 
The soil on which the experiment was conducted, was brought from the

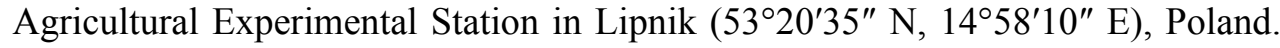
The soil belongs to the typical rusty soil group (Polish Soils Systematics 2011) and is classified as Haplic Cambisol (WRB 2014). At the Ap level (arable-humus horizon), it has a granulometric composition of clay sand with a slightly acidic $\mathrm{pH}$.

The application of the preparation and fertilization was performed before sowing the cereals. Sowing was carried out successively, on 21 May, 2016 and on 22 May, 2017. The seeds were placed in plots (12 plots for buckwheat, and 12 plots for millet) with 75 seeds plot $^{-1}$ of buckwheat and millet each. Soil samples were collected for chemical analysis after harvest: in 2016: 30 August - buckwheat, 29 September - millet, in 2017: 28 August - buckwheat, 28 September - millet. After harvesting, the grain yield $\left(\mathrm{g} \mathrm{plot}^{-1}\right)$ was determined.

The experiment was planned using a completely random design, in three replications. The plot size was $1 \mathrm{~m}^{2}$. The experiment included four combinations: control (without $\mathrm{EM}$ and fertilization), ammonium nitrate, manure, effective microorganisms (EM).

Measurements of leaf greenness in each year were taken using a chlorophyll meter - SPAD 520 (Minolta) in stages: flowering (BBCH 60-69), fruit development (BBCH 70-79) and ripening (BBCH 80-89), for millet, in stages: shoot development (BBCH 30-39), fruit development (60-69) and ripening (BBCH 8089). The measurements (index of leaf greenness - SPAD index) were conducted on fully developed leaves without any signs of ageing or mechanical damage.

The plots were protected from atmospheric precipitation. The humidity of the plots was controlled continuously. During the period of intensive growth and development of both plant species (critical stages in development), humidity was maintained at $60-70 \%$ of the field water capacity, which is the optimal value of soil moisture for both buckwheat and millet.

Soil samples were taken from each plot to form a pooled sample for the experimental combination after harvesting. The soil $\mathrm{pH}_{\mathrm{KCl}}$ was determined using the potentiometric method according to ISO 10390/1997. The amount of organic carbon $\left(\mathrm{C}_{\text {org }}\right)$ was determined using the Westerhoff colorimetric method. The concentration of total nitrogen $(\mathrm{N})$ was determined in samples mineralized in sulfuric (VI) acid with $\mathrm{H}_{2} \mathrm{O}_{2}-\mathrm{Kjeldahl}$ method. The content of available phosphorus $(\mathrm{P})$ and potassium $(\mathrm{K})$ in the soil was determined using the Egner-Riehm (DL) method. For the determination of the amount of calcium $(\mathrm{Ca})$ and magnesium $(\mathrm{Mg})$ in the soil, an extraction was performed using a buffered barium chloride solution at $\mathrm{pH}=8.1$ (ISO 13536:2002P).

The total content of metals: iron (Fe), zinc ( $\mathrm{Zn})$, manganese (Mn) and copper $(\mathrm{Cu})$ was determined in soil samples after wet combustion in a mixture of nitric $(\mathrm{V})$ and chloric(VII) acids (ISO 11047:2001). Analyses were performed using a spectrometer Atomic Absorption iCE 3000 Series (Thermo Fisher Scientific). 
The mineral composition of the grain was determined after the plants were harvested. Material for the macroelement concentration analyses was subjected to digestion in concentrated sulfuric acid $\left(\mathrm{H}_{2} \mathrm{SO}_{4}\right)$ and perchloric acid $\left(\mathrm{HClO}_{4}\right)$, whilst the material for microcomponent concentration analyses was subjected to digestion in a nitric acid $\left(\mathrm{HNO}_{3}\right)$ and perchloric acid $\left(\mathrm{HClO}_{4}\right)$ mixture. The concentration of $\mathrm{N}$ was determined using the Kjeldahl method. The concentration of $\mathrm{P}$ was determined using a colorimetric method with a Specol 221. An atomic absorption spectrometer was used to determine $\mathrm{K}, \mathrm{Na}$ and $\mathrm{Ca}$ by means of emulsion flame spectroscopy, as well as $\mathrm{Mg}, \mathrm{Zn}$, $\mathrm{Fe}$, molybdenum (Mo), $\mathrm{Mn}$ and $\mathrm{Cu}$, by means of absorption flame spectroscopy.

All data were analysed using the software Statistica, version 12 (Statsoft). In order to determine the significance of differences in the SPAD index, the content of macro- and microelements in grain and soil and the yield of the plants were determined, also a one-way analysis of variance (ANOVA) was conducted. The significance of differences between the means was compared by means of Tukey's multiple range tests. Statistical significance was considered to occur at $p \leq 0.05$. Different letters in columns symbolize significantly different groups.

\section{RESULTS AND DISCUSSION}

The average yield of buckwheat seeds is, according to the data contained in the literature of the subject, at a level ranging from 850 to $990 \mathrm{~kg} \mathrm{ha}^{-1}$ (Kalinova et al. 2005), depending on the variety. According to Adams et al. (2016), over the course of 16 years, the minimum millet crop yield was less than $100 \mathrm{~kg} \mathrm{ha}^{-1}$ and maximum was greater than $1650 \mathrm{~kg} \mathrm{ha}^{-1}$. In own research, depending on the fertilization applied, the buckwheat yield ranged from 85.5 to $84.0 \mathrm{~g} \mathrm{plot}^{-1}$, i.e. 855 to $840 \mathrm{~kg} \mathrm{ha}^{-1}$. The average yield of millet ranged from 24.6 to $23.4 \mathrm{~g} \mathrm{plot}^{-1}$, i.e. 246 to $234 \mathrm{~kg} \mathrm{ha}^{-1}$ (Fig. 1). Although a statistically significant variation in the yield of buckwheat and

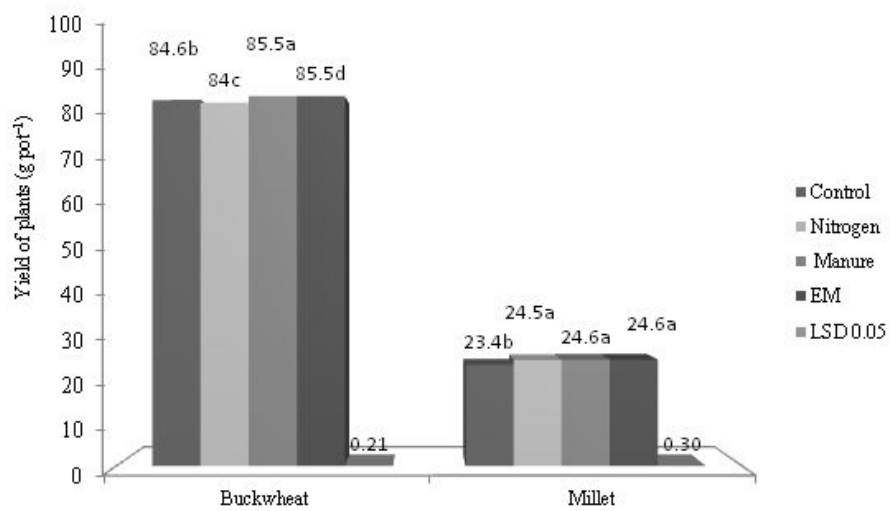

Fig. 1. Yield of Buckwheat and Millet $\left(\mathrm{g} \mathrm{pot}^{-1}\right)$. Letters express statistical differences between fertilization treatments (Tukey test, $\alpha=0.05$ ) 
millet between the individual experimental variants was recorded, these differences were insignificant. The application of fertilization with manure significantly increased the buckwheat yield by $0.18 \mathrm{~g} \mathrm{plot}^{-1}$ (i.e. $1 \%$ ) as compared to the control. Plants grown in plots, in which EM were used, produced the lowest yields (by $0.27 \mathrm{~g} \mathrm{plot}^{-1}$ lower yield of grain, i.e. 1.6\%, with reference to the control). The beneficial effect of the biological preparations depends on the type of agent used, its dose and the species of plant (Kocoń and Gałązka 2015), which may partially explain the poor reaction of buckwheat to EM used in own research. Similar results were obtained by Priyadi et al. (2005), who recorded an increase in corn yield after the application of chicken manure, while EM did not have any effect. There is also some information in Polish and foreign literature (Piskier 2006; Muthaura et al. 2010) that refers to the introduction of preparations with useful microorganisms, and the improvement in crop yields that may be obtained, this finding was confirmed by our own research. A significantly higher yield of millet, compared to the control, was recorded in plots with $\mathrm{N}$ fertilization, manure and EM, on average $0.225 \mathrm{~g} \mathrm{plot}^{-1}$, i.e. $5 \%$. An increase in the yield of millet was reported as a result of mineral fertilization and the application of bovine manure in doses reduced in relation to the recommendations, Adams et al. (2016).

The chlorophyll content in leaves is influenced by genetic features, the plant development phase, the availability of nutrients and climatic and soil conditions. Its concentration increases significantly after the use of macroelements and in particular N fertilization (Hokmalipour and Darbandi 2011). The chlorophyll content in the leaves of both species differed significantly, depending on the development phase and the type of fertilizer applied. Leaves fertilized with mineral fertilizer contained significantly more chlorophyll than those of the control plants, an average of $53 \%$ more for buckwheat and $87 \%$ for millet (Tab. 1). The largest concentration of chlorophyll was observed in buckwheat leaves in the BBCH 70-79 stage. Millet leaves contained the most chlorophyll in the $\mathrm{BBCH}$ 80-89 stage.

According to many researchers, the use of EM favours the production of organic matter, lowering the soil $\mathrm{pH}$, and increasing the uptake of water and nutrients by plants, because it can mitigate the effects of stress in the plant and thus contribute to an increase in chlorophyll concentration in leaves (Amro et al. 2014). Muthaura et al. (2010) did not find significant differences in the chlorophyll content of leaves among the different treatments applied (manure, microorganisms, control), although according to the authors, the content of chlorophyll $\mathrm{a}$ and $\mathrm{b}$ was slightly higher in plants inoculated with effective microorganisms. In our own research, the leaves of plants fertilized with EM were characterized by the lowest concentration of chlorophyll in comparison with those fertilized by mineral fertilizers and manure. The exceptions were buckwheat leaves in the BBCH 70-79 and 80-89 stages (Tab. 1), where the highest chlorophyll concentration was found after the application of EM among the experimental variants. In the early stages of leaf growth, the synthesis of 
chlorophyll, proteins and structural compounds is high, which results in a high level of catabolism in order to meet the energy needs of the plants (Muthaura et al. 2010). In the experiment carried out, an increase in the chlorophyll concentration of the leaves followed gradually with the growth of plants. Only in the buckwheat leaves fertilized with mineral fertilizer and manure, in the BBCH 70-79 and 80-89 stages, was a gradual decrease in the concentration of green pigments observed, which may be a result of the specificity of the species grown, the age of the leaves or the reaction of the species to the fertilizer applied (Yang et al. 2014b).

Table 1. SPAD index readings at particular stages of vegetation in buckwheat and millet cultivation

\begin{tabular}{lccccc}
\hline \multicolumn{1}{c}{ Item } & Fertilization & \multicolumn{3}{c}{ Vegetation phase (BBCH) } & Mean \\
\hline & & Flowering & Fruit development & Ripening & \\
& & $(60-69)$ & $(70-79)$ & $(80-89)$ & \\
\hline Buckwheat & Control & $13.5 \mathrm{~d}$ & $18.3 \mathrm{~d}$ & $21.1 \mathrm{~b}$ & $17.6 \mathrm{~d}$ \\
& Nitrogen & $35.5 \mathrm{a}$ & $26.5 \mathrm{c}$ & $19.1 \mathrm{~d}$ & $27.0 \mathrm{a}$ \\
& Manure & $31.8 \mathrm{~b}$ & $27.5 \mathrm{~b}$ & $20.1 \mathrm{c}$ & $26.5 \mathrm{~b}$ \\
& EM & $15.6 \mathrm{c}$ & $29.1 \mathrm{a}$ & $29.5 \mathrm{a}$ & $24.7 \mathrm{c}$ \\
Mean & & 24.1 & 25.3 & 22.5 & 23.9 \\
LSD $_{0.05}$ & & 2.93 & 3.53 & 1.61 & 2.37 \\
\hline Millet & & Shoot development & Fruit development & Ripening & \\
& & $(30-39)$ & $(60-69)$ & $(80-89)$ & \\
& Control & $14.7 \mathrm{~d}$ & $19.2 \mathrm{~d}$ & $21.0 \mathrm{~d}$ & $18.3 \mathrm{~d}$ \\
& Nitrogen & $28.2 \mathrm{a}$ & $32.7 \mathrm{a}$ & $41.9 \mathrm{a}$ & $34.3 \mathrm{a}$ \\
Mean & Manure & $23.4 \mathrm{~b}$ & $30.5 \mathrm{~b}$ & $32.8 \mathrm{~b}$ & $28.9 \mathrm{~b}$ \\
LSD $_{0.05}$ & EM & $15.2 \mathrm{c}$ & $20.2 \mathrm{c}$ & $22.5 \mathrm{c}$ & $19.3 \mathrm{c}$ \\
& & 20.4 & 25.6 & 29.6 & 25.2 \\
& & 2.99 & 4.15 & 1.52 & 2.54 \\
\hline
\end{tabular}

The chemical composition of plants can be modified by many factors, both genetic and agrotechnical, this is directly related to the nutritional value of food products supplied for human consumption. The mineral content of buckwheat and millet grains was significantly different in individual research variants, which may indicate the different abilities of absorption and accumulation of these components by specific species cultivated under different fertilization conditions (Tab. 2). The average mineral content in the analysed buckwheat grain was higher compared to the data found in the literature (Thi et al. 2014). The most beneficial mineral composition was characterized for buckwheat seed harvested from plots fertilized with manure. Compared to the control, grain fertilized with manure contained significantly more $\mathrm{N}$ (by $5 \%$ ), $\mathrm{Mg}$ (by $8 \%$ ), $\mathrm{Mn}$ (by $58 \%$ ), $\mathrm{Cu}$ (by $51 \%$ ) and Mo (by $14 \%$ ). For the buckwheat grain grown in plots, on which EM were applied, significantly more $\mathrm{K}$ (by $2 \%$ ), $\mathrm{Mg}$ (by 12\%), $\mathrm{Cu}$ (by 37\%) and $\mathrm{Fe}$ (by 14\%) were found. The application of the microbial preparation facilitated the uptake of $\mathrm{K}, \mathrm{Mg}, \mathrm{Cu}$ and $\mathrm{Fe}$ by the plant (Radkowski and Radkowska 2018). Grain harvested from plots treated with a mineral fertilizer was significantly more abundant in $\mathrm{Ca}$ (by $33 \%$ ), $\mathrm{Cu}$ (by 51\%), Mo (by $8 \%$ ) and Zn (by 37\%). 
Table 2. Macro- and microelements content in grain and in buckwheat and millet cultivation

\begin{tabular}{|c|c|c|c|c|c|c|c|c|c|c|c|}
\hline \multirow[b]{2}{*}{ Item } & $\mathrm{N}$ & $\mathrm{P}$ & K & $\mathrm{Mg}$ & $\mathrm{Ca}$ & $\mathrm{Na}$ & $\mathrm{Mn}$ & $\mathrm{Cu}$ & $\mathrm{Fe}$ & Mo & $\mathrm{Zn}$ \\
\hline & \multicolumn{6}{|c|}{$\mathrm{g} \mathrm{kg}^{-1}$ d.m. } & \multicolumn{5}{|c|}{$\mathrm{mg} \mathrm{kg}^{-1}$ d.m. } \\
\hline & \multicolumn{6}{|c|}{ Buckwheat } & & & & & \\
\hline Control & $18.7^{\mathrm{b}}$ & $10.3^{\mathrm{a}}$ & $9.21^{\mathrm{b}}$ & $1.86^{\mathrm{c}}$ & $0.49^{\mathrm{c}}$ & $0.087^{\mathrm{a}}$ & $25.2^{\mathrm{c}}$ & $4.60^{\mathrm{c}}$ & $31.2^{\mathrm{c}}$ & $13.0^{\mathrm{a}}$ & $43.5^{\mathrm{b}}$ \\
\hline Nitrogen & $20.2^{\mathrm{a}}$ & $6.33^{\mathrm{c}}$ & $8.22^{\mathrm{d}}$ & $1.94^{\mathrm{b}}$ & $0.65^{\mathrm{a}}$ & $0.080^{\mathrm{c}}$ & $38.3^{\mathrm{b}}$ & $6.96^{\mathrm{a}}$ & $33.8^{\mathrm{b}}$ & $14.0^{\mathrm{a}}$ & $59.8^{\mathrm{a}}$ \\
\hline Manure & $19.7^{\mathrm{a}}$ & $7.66^{\mathrm{b}}$ & $8.78^{\mathrm{c}}$ & $2.01^{\mathrm{a}}$ & $0.57^{\mathrm{b}}$ & $0.075^{\mathrm{d}}$ & $39.6^{\mathrm{a}}$ & $6.97^{\mathrm{a}}$ & $31.0^{\mathrm{c}}$ & $14.8^{\mathrm{a}}$ & $46.6^{\mathrm{b}}$ \\
\hline EM & $15.7^{\mathrm{c}}$ & $8.10^{\mathrm{b}}$ & $9.37^{\mathrm{a}}$ & $2.09^{\mathrm{a}}$ & $0.48^{\mathrm{c}}$ & $0.085^{\mathrm{b}}$ & $26.8^{\mathrm{c}}$ & $6.29^{\mathrm{b}}$ & $35.5^{\mathrm{a}}$ & $13.0^{\mathrm{a}}$ & $46.3^{\mathrm{b}}$ \\
\hline $\operatorname{LSD}_{0.05}$ & 0.81 & 0.419 & 0.075 & 0,038 & 0.024 & 0.0178 & 1,91 & 0.650 & 1.68 & n.s. & 1.77 \\
\hline & $12.4^{\mathrm{c}}$ & $6.34^{\mathrm{b}}$ & $7.67^{\mathrm{c}}$ & $1.24^{\mathrm{c}}$ & $0.17^{\mathrm{b}}$ & $0.097^{\mathrm{a}}$ & $12.2^{\mathrm{c}}$ & $5.59^{\mathrm{a}}$ & $99.9^{\mathrm{a}}$ & $14.0^{\mathrm{a}}$ & $34.5^{\mathrm{c}}$ \\
\hline Nitrogen & $17.3^{\mathrm{a}}$ & $7.37^{\mathrm{a}}$ & $8.00^{\mathrm{a}}$ & $1.43^{\mathrm{a}}$ & $0.49^{\mathrm{a}}$ & $0.090^{\mathrm{c}}$ & $18.2^{\mathrm{a}}$ & $1.88^{\mathrm{c}}$ & $52.9^{\mathrm{d}}$ & $12.8^{\mathrm{a}}$ & $44.5^{\mathrm{a}}$ \\
\hline Manure & $17.2^{\mathrm{a}}$ & $7.50^{\mathrm{a}}$ & $7.21^{\mathrm{d}}$ & $1.25^{\mathrm{c}}$ & $0.15^{\mathrm{c}}$ & $0.097^{\mathrm{a}}$ & $11.7^{\mathrm{c}}$ & $4.09^{\mathrm{b}}$ & $80.3^{\mathrm{c}}$ & $13.9^{\mathrm{a}}$ & $41.3^{\mathrm{b}}$ \\
\hline EM & $14.1^{\mathrm{b}}$ & $7.22^{\mathrm{a}}$ & $7.89^{\mathrm{b}}$ & $1.30^{\mathrm{b}}$ & $0.14^{\mathrm{c}}$ & $0.093^{\mathrm{b}}$ & $13.6^{\mathrm{b}}$ & $5.35^{\mathrm{a}}$ & $88.2^{\mathrm{b}}$ & $13.6^{\mathrm{a}}$ & $34.6^{\mathrm{c}}$ \\
\hline $\operatorname{LSD}_{0.05}$ & 0.96 & 0.440 & 0.099 & 0.019 & 0.020 & 0.0774 & 0.73 & 0.531 & 2.38 & n.s. & 0.26 \\
\hline
\end{tabular}

DM - dry matter; ns - not significant.

According to the literature data on the subject (Kalinová 2002), mineral compounds constitute from 1.5 to $4.2 \%$ of the millet grain. The millet grain studied was abundant in K, Fe and Mn, which confirms the reports of Kalinová (2002) and Dembiras (2005). According to the authors quoted, millet is also an excellent source of $\mathrm{Cu}$ and $\mathrm{Zn}$, which are important components in the structures of enzymes, this is also confirmed by our own research. The analysed millet responded best to mineral fertilization (Tab. 3). Grain from plots fertilized with mineral fertilizer, compared to the control, contained significantly more $\mathrm{N}, \mathrm{P}, \mathrm{K}, \mathrm{Mg}, \mathrm{Ca}, \mathrm{Zn}$ and $\mathrm{Mn}$, by 40, 16, 4, $15,188,49$ and $29 \%$, respectively. The manure used contributed to increasing the concentration of $\mathrm{N}$ and $\mathrm{P}$ by 39 and $18 \%$, respectively. Grains collected from EM plots contained $14 \%$ more $\mathrm{P}$ and $11 \%$ more $\mathrm{Mn}$ than those from control plots, which correspond to the results of studies conducted by Radkowski and Radkowska (2018).

Table 3. The ratio of mineral components in buckwheat and millet grains

\begin{tabular}{lcccc}
\hline \multicolumn{1}{r}{ Item } & Ca:Mg & Ca:P & K:Mg & Na:K \\
\hline Control & 0.26 & Buckwheat & & \\
Nitrogen & 0.33 & 0.05 & 4.95 & 0.009 \\
Manure & 0.28 & 0.10 & 4.24 & 0.010 \\
EM & 0.23 & 0.07 & 4.37 & 0.009 \\
& & 0.06 & 4.48 & 0.009 \\
Control & 0.14 & Millet & & \\
Nitrogen & 0.34 & 0.03 & 6.18 & 0.013 \\
Manure & 0.12 & 0.07 & 5.59 & 0.011 \\
EM & 0.11 & 0.02 & 5.77 & 0.013 \\
\hline
\end{tabular}

In a properly balanced diet, which provides the body with minerals necessary for good health, their proper distribution should be ensured first (Tab. 3). Their ratio is of decisive importance to their bioavailability. The absorption of individual elements may be increased or weakened by the supply of other elements. According to Majkowska-Gadomska (2006), the ratio of Ca to Mg should not exceed a value 
of 3, which confirms that the grain of the studied species could be a good source of the discussed elements. Higher proportions of Ca:Mg, according to Francke (2010), may indicate a shortage of $\mathrm{Mg}$ in a food. The most well-known minerals are $\mathrm{Ca}$ and $\mathrm{Mg}$, they are present in the largest amount in the body and bone structure. Their correct ratio in food should be above 1 (Ihedioha and Okoye 2011). In the analysed grain of both species, the $\mathrm{Ca}: \mathrm{P}$ ratio was below the normal values. According to data presented by Majkowska-Gadomska (2006), the correct proportions of $\mathrm{K}: \mathrm{Mg}$ in a diet should not exceed 6 . In the examined material, only for the millet grain collected from the control and EM-fertilized plots, were the proportions of both elements slightly exceeded. An important role in regulating blood pressure is played by the correct Na:K ratio, which for both buckwheat and millet grains was in accordance with data available in the literature, i.e. below 1 (Yusuf et al. 2007).

Resistance to stress factors, and the size and quality of crop yields depends mainly on soil fertility. The abundance of the digestible form of the nutrients determines soil fertility. The correct soil $\mathrm{pH}$ significantly affects the balance and availability of macroelements for plants. Buckwheat and millet produce the best yields from soils close to neutral $\mathrm{pH}$. The best growth conditions for both species were found in plots, in which manure was used (Tab. 4).

Table 4. Acidity $\left(\mathrm{pH}_{\mathrm{KCl}}\right)$, organic carbon $\left(\mathrm{C}_{\mathrm{org}}\right)$, total nitrogen $(\mathrm{N})$, available phosphorus and potassium $(\mathrm{K})$, replaceable magnesium $(\mathrm{Mg})$ and calcium $(\mathrm{Ca})$ in soil in the cultivation of buckwheat and millet

\begin{tabular}{|c|c|c|c|c|c|c|c|c|}
\hline \multirow{2}{*}{ Item } & \multirow{2}{*}{$\mathrm{pH}_{\mathrm{kcl}}$} & $\mathrm{C}_{\text {org }}$ & $\mathrm{N}$ & $\mathrm{P}$ & $\mathrm{K}$ & $\mathrm{Mg}$ & $\mathrm{Ca}$ & $\mathrm{C}: \mathrm{N}$ \\
\hline & & \multicolumn{2}{|c|}{$\mathrm{g} \mathrm{kg}^{-1}$ d.m. } & \multicolumn{5}{|c|}{$\mathrm{mg} \mathrm{kg}^{-1}$ d.m. } \\
\hline \multirow{6}{*}{$\begin{array}{l}\text { Control } \\
\text { Nitrogen } \\
\text { Manure } \\
\text { EM } \\
\text { LSD }_{0.05}\end{array}$} & & & $\mathrm{Bu}$ & kwheat & & & & \\
\hline & $6.01^{\mathrm{b}}$ & $7.87^{\mathrm{c}}$ & $0.57^{\mathrm{b}}$ & $85.2^{\mathrm{b}}$ & $33.2^{\mathrm{c}}$ & $84.5^{\mathrm{d}}$ & $425.3^{\mathrm{d}}$ & $14: 1$ \\
\hline & $6.16^{\mathrm{b}}$ & $8.65^{\mathrm{b}}$ & $0.52^{\mathrm{b}}$ & $69.3^{c}$ & $19.7^{\mathrm{d}}$ & $116.0^{\mathrm{c}}$ & $468.5^{\mathrm{c}}$ & $16: 1$ \\
\hline & $6.93_{\mathrm{a}}$ & $9.30^{\mathrm{a}}$ & $0.75^{\mathrm{a}}$ & $107.5^{\mathrm{a}}$ & $87.9^{\mathrm{a}}$ & $217.0^{\mathrm{a}}$ & $737.2^{\mathrm{a}}$ & $12: 1$ \\
\hline & $6.32^{\mathfrak{b}}$ & $8.85^{\mathrm{b}}$ & $0.63^{\mathrm{ab}}$ & $87.6^{\mathrm{b}}$ & $44.0^{\mathrm{b}}$ & $130.0^{\mathrm{b}}$ & $503.0^{\mathrm{b}}$ & $14: 1$ \\
\hline & 0.029 & 0.36 & 0.134 & 7.23 & 6.14 & 3.89 & 13.91 & \\
\hline Control & \multicolumn{8}{|c|}{ Millet } \\
\hline Nitrogen & $5.72^{\mathrm{c}}$ & $8.17^{\mathrm{b}}$ & $0.60^{\mathrm{b}}$ & $75.2^{\mathrm{c}}$ & $10.4^{\mathrm{d}}$ & $86.9^{\mathrm{d}}$ & $476.3^{\mathrm{bc}}$ & $14: 1$ \\
\hline Manure & $7.42^{\mathrm{a}}$ & $11.0^{\mathrm{a}}$ & $0.88^{\mathrm{a}}$ & $173.9^{\mathrm{a}}$ & $149.1^{\mathrm{a}}$ & $344.4^{\mathrm{a}}$ & $1003.1^{\mathrm{a}}$ & $12: 1$ \\
\hline EM & $6.29^{\mathrm{b}}$ & $7.88^{\mathrm{b}}$ & $0.61^{\mathrm{b}}$ & $107.6^{\mathrm{b}}$ & $40.1^{\mathrm{b}}$ & $98.2^{\mathrm{c}}$ & $430.1^{\mathrm{c}}$ & $13: 1$ \\
\hline $\operatorname{LSD}_{0.05}$ & 0.203 & 0.497 & 0.068 & 5.64 & 1.17 & 2.05 & 51.1 & \\
\hline
\end{tabular}

The study indicated that the application of EM has no significant effects on soil $\mathrm{pH}$, which correlates with the results of studies by Jakubus et al. (2010) and Radkowski and Radkowska (2018). The soil fertilized with manure was characterized by the highest content of $\mathrm{C}_{\text {org }}$ among all of the experimental variants, by $18 \%$ in buckwheat plots and by $42 \%$ in plots with millet, compared to the control. An increase in the $\mathrm{C}_{\text {org }}$ content due to the use of manure was also confirmed by Siwik-Ziomek and Lemanowicz (2014). With regard to the control, for both buckwheat and millet cultivation, the highest increase in mineral content was observed for the plots, in which manure was used. After the application of manure, the soil contained more $\mathrm{N}, \mathrm{K}, \mathrm{P}, \mathrm{Mg}$ and $\mathrm{Ca}$, respectively for 
buckwheat by 32, 26, 164, 156 and $73 \%$, and for millet by $49,118,329,195$ and $98 \%$. According to researchers (Jakubus et al. 2010), there is a relationship between the influence of effective microorganisms on the soil nutrient content and the type of soil. The authors concluded that increasing the doses of the EM-preparation increased the quantities of available $\mathrm{K}, \mathrm{Mg}$ and mineral $\mathrm{N}$ values in the grey-brown podzolic soil. On the other hand, in the case of the proper black earth, the concentrations of available $\mathrm{K}, \mathrm{Mg}$ and other mineral components decreased. Although statistically significant, the differences in the concentrations of the majority of the analysed macronutrients were not confirmed, there was an upward trend in the plots, on which EM were applied. Ramakrishnaiah and Vijaya (2013) reported the positive effects of bio-preparations on the concentration of N, P and K in soil. An increased accumulation of $\mathrm{K}$ in the soil after the use of bio-inoculants was also proved by Bohrer et al. (2003) and by Radkowski and Radkowska (2018). A reduction in the level of absorbable forms of Mg in soil treated with EM (by 16\%, in millet cultivation) was confirmed Zydlik and Zydlik (2008). According to the authors cited, $\mathrm{Mg}$ was taken up by plants.

The C:N ratio affects the decomposition of organic matter and determines the availability of $\mathrm{N}$ for plants. A ratio higher than 20:1 favours the immobilization of $\mathrm{N}$, while for one below $15: 1$, mineralization is dominant. With the exception of soil fertilized with mineral fertilizers during the growth of buckwheat, the $\mathrm{C}: \mathrm{N}$ ratio did not exceed 15:1 (Tab. 4).

Table 5. Microelements content in soils used for buckwheat and millet cultivation

\begin{tabular}{lrcrr}
\hline \multirow{2}{*}{ Item } & \multicolumn{2}{c}{$\mathrm{Fe}$} & $\mathrm{Zn}$ & $\mathrm{Cu}$ \\
\cline { 2 - 5 } & \multicolumn{4}{c}{$\mathrm{mg} \mathrm{kg}^{-1} \mathrm{DM}$} \\
Control & $6063.8 \mathrm{a}$ & Buckwheat & $7.30 \mathrm{~b}$ & $181.4 \mathrm{a}$ \\
Nitrogen & $5697.9 \mathrm{c}$ & $49.8 \mathrm{~d}$ & $6.78 \mathrm{~b}$ & $172.5 \mathrm{~b}$ \\
Manure & $5914.9 \mathrm{~b}$ & $53.8 \mathrm{~b}$ & $8.65 \mathrm{a}$ & $179.0 \mathrm{a}$ \\
EM & $5616.5 \mathrm{~d}$ & $55.1 \mathrm{a}$ & $6.84 \mathrm{~b}$ & $180.4 \mathrm{a}$ \\
LSD & 29.56 & $50.7 \mathrm{c}$ & 0.842 & 2.89 \\
& & 0.84 & & $182.7 \mathrm{c}$ \\
Control & $5714.8 \mathrm{c}$ & Millet & $6.86 \mathrm{~d}$ & $188.9 \mathrm{~b}$ \\
Nitrogen & $5917.2 \mathrm{a}$ & $50.3 \mathrm{c}$ & $9.86 \mathrm{~b}$ & $208.6 \mathrm{a}$ \\
Manure & $5857.5 \mathrm{~b}$ & $56.2 \mathrm{~b}$ & $11.9 \mathrm{a}$ & $188.2 \mathrm{~b}$ \\
EM & $5831.8 \mathrm{~b}$ & $66.3 \mathrm{a}$ & $7.88 \mathrm{c}$ & 1.95 \\
LSD & 46.63 & $50.4 \mathrm{c}$ & 0.592 & \\
\hline
\end{tabular}

DM - dry matter.

An increase in the content of $\mathrm{Cu}$ and $\mathrm{Zn}$ in soil under the influence of manure fertilization was confirmed by the studies of Rutkowska et al. (2009). In the cultivation of buckwheat in soil fertilized with manure, a significantly higher concentration of $\mathrm{Zn}$ and $\mathrm{Cu}$ was found compared to the control plots, on average by 11 and $18 \%$ (Tab. 5). In the cultivation of millet, fertilization with manure significantly increased the $\mathrm{Zn}$ content by $31 \%$, $\mathrm{Cu}$ by $73 \%$ and $\mathrm{Mn}$ by $14 \%$. The greatest amount of $\mathrm{Fe}$ was 
found in soil fertilized with mineral fertilizers (by 4\%). According to Behera et al. (2011) the content of $\mathrm{Zn}$ in soil increases under the influence of organic matter compounds, because this element forms labile organic-mineral complexes.

\section{CONCLUSIONS}

1. The studied buckwheat and millet species responded with significantly higher yields to natural fertilization. The buckwheat grain fertilized with manure was characterized by the highest concentration of nitrogen $(\mathrm{N})$, magnesium $(\mathrm{Mg})$, manganese $(\mathrm{Mn})$, copper $(\mathrm{Cu})$ and molybdenum $(\mathrm{Mo})$. For millet grain fertilized with manure, the highest amounts of $\mathrm{N}$, phosphorus $(\mathrm{P})$, sodium $(\mathrm{Na})$ and Mo were found. The application of manure also positively influenced the chemical properties of the soil, increasing the $\mathrm{pH}$ of the soil to values beneficial for the growth of buckwheat and millet, as well as having a beneficial influence over the content of minerals necessary for plant growth and development.

2. It is difficult to definitely confirm the positive effect of the applied preparation with effective microorganisms in the cultivation of buckwheat and millet. However, their positive role should be emphasized, especially in relation to the soil. For the buckwheat plots, on which effective microorganisms (EM) were applied, there was an upward trend in the concentration of the investigated macronutrients in the soil, and it was significantly higher in the case of $\mathrm{N}, \mathrm{P}, \mathrm{K}, \mathrm{Mg}$ and $\mathrm{Ca}$ than in plots fertilized with a mineral fertilizer. A similar situation was observed in the cultivation of millet, where significantly more $\mathrm{N}, \mathrm{P}, \mathrm{K}$ and $\mathrm{Mg}$ were recorded than after the application of mineral fertilizers.

3. Both the research results discussed above and a number of similar experiments conducted in Poland and abroad support a reduction in the use of mineral fertilizers in favour of natural fertilizers, especially in the cultivation of plants for human and animal consumption, and for production that does not threaten the natural environment. Further research is also required to examine the impact of EM in subsequent years. The experiment conducted shows that microbiological preparations can improve the chemical properties of the soil, and the nature of their activity may depend on their type, dose, species of plant, the stage of development during which it is applied, and the prevailing climate and soil conditions.

Conflict of interest: The Authors does not declare conflict of interest. 


\section{REFERENCES}

Adams A.M., Gillespie A.W., Kar G., Koala S., Ouattara B., Kimaro A.A., Bationo A. Akponikpe P.B.I., Schoenau J.J., Peak D., 2016. Long term effects of reduced fertilizer rates on millet yields and soil properties in the West-African Sahel. Nutr. Cycl. Agroecosys., 106, 17-29, https://doi 10.1007/s10705-016-9786-x

Aktar M.W., Sengupta D., Chowdhury A., 2009. Impact of pesticides use in agriculture: their benefits and hazards. Interdiscip. Toxicol., 2(1), 1-12, https://doi: 10.2478/v10102-009-0001-7

Amro S.M., Salama, Omima M., El-Sayed, Osama H.M., El Gammal., 2014. Effect of effective microorganisms (EM) and potassium sulphate on productivity and fruit quality of "Hayany" date palm grown under salinity stress. J. Agric. Vet. Sci., 6, 90-99, https://doi: 10.9790/2380-07619099

Babaeian M., Esmaeilian Y., Tavassoli A., Asgharzade A., Sadeghi M., 2011. The effects of water stress, manure and chemical fertilizer on grain yield and grain nutrient content in barley. Sci. Res. Essays., 6, 3697-3701, https://doi: 10.5897/SRE11.602

Behera S.K., Singh M.V., Singh K.N., Todwal S., 2011. Distribution variability of total extractable zinc in cultivated acid soils of India and their relationship with some selected soil properties. Geoderma, 162, 242-250, https://doi: 10.1016/j.geoderma.2011.01.016

Bohrer G., Kagan-Zur V., Roth-Bejerano N., Ward D., Beck G., Bonifacio E., 2003. Effects of different Kalahari-desert VA mycorrhizal communities on mineral acquisition and depletion from the soil by host plants. J. Arid Environ., 55(2), 193-08, https://doi: 10.1016/S0140-1963(03)00047-8

Dąbrowska G., Zdziechowska E., 2015. The role of rhizobacteria in the stimulation of the growth and development processes and protection of plants against environmental factors. Progress in Plant Protection, 55, 498-506.

Dembiras A., 2005. Glucan and mineral nutrient contents of cereals grown in Turkey. Food Chem., 90, 773-777, https://doi: 10.1016/j.foodchem.2004.06.003

Estrada-Campuzano G., Slafer G.A., Miralles D.J., 2012. Differences in yield, biomass and their components between triticale and wheat grown under contrasting water and nitrogen environments. Field Crop. Res., 128, 167-179, https://doi: 10.1016/j.fcr.2012.01.003

Francke A., 2010. The effect of magnesium fertilization on the macronutrient content of Pepinodulce (Solanum muricatum Aiton) fruit. J Elem., 15, 467-475, https://doi: 10.5601/jelem.2010.15.3.467-475

Hokmalipour S., Darbandi M.H., 2011. Effects of nitrogen fertilizer on chlorophyll content and other leaf indicate in three cultivars of maize (Zea mays L.). World Appl. Sci. J., 15, 1780-1785

Ihedioha J.N., Okoye C.O.B., 2011. Nutritional evaluation of Mucuna flagellipes L. leaves: an underutilized legume in Eastern Nigeria. Am. J. Plant Nutr. Fert. Technol., 1, 55-63, https://doi: 10.3923/ajpnft.2011.55.63

Jakubus M., Kaczmarek Z., Gajewski P., 2010. Influence of increasing doses of EM-A preparation on properties of arable soils. Part II. Chemical properties (in Polish). Journal of Research and Applications in Agricultural Engineering, 53, 128-132.

Kaczmarek Z., Owczarzak W., Mrugalska L., Grzelak M., 2007. The influence of effective microorganisms for some of physical and water properties on arable-humus horizons of mineral soils (in Polish). Journal of Research and Applications in Agricultural Engineering, 52, 73-77.

Kalinová J., 2002. Comparison of productivity and quality in common buckwheat and proso millet (in Czech): doctoral dissertation. University of South Bohemia, 175.

Kalinová J., Moudrý J., Čurn V., 2005. Yield formation in common buckwheat (Fagopyrum Esculentum Moench). Acta Agronomica Hung., 53, 283-291, https://doi: 10.1556/AAgr.53.2005.3.5

Khaliq A., Abbasi M.K., Hussain T., 2006. Effect of integrated use of organic and inorganic nutrient sources with effective microorganisms (EM) on seed cotton yield in Pakistan. Bioresour. Technol., 97, 967-972, https://doi: 10.1016/j.biortech.2005.05.002 
Khan H.Z., Iqbal S., Akbar N., Saleem M.F., Iqbal A., 2013. Integrated management of different nitrogen sources for maize production. Pak. J. Agric. Sci., 50, 55-61.

Koziara W., Panasiewicz K., Sulewska H., Sobieszczański R., 2015. Effect of selected factors on yield and seed. Fragm. Agron., 32, 73-81.

Linh NTN., Khoa AVD., Halas V., 2014. Buckwheat as valuable feed and food resource. NJMBS, 2 , 1-8, https://doi: 10.20286/nova-jmbs-030459

Mahmood F., Khan I., Ashraf U., Shahzad T., Hussain S., Shahid M., Abid M., Ullah S., 2017. Effects of organic and inorganic manures on maize and their residual impact on soil physico-chemical properties. J. Soil Sci. Plant Nutr., 17, 22-32, https://doi: 10.4067/S0718-95162017005000002

Majkowska-Gadomska J., 2006. Effect of sorbents on concentrations of some trace elements in butter-head lettuce (Lactuca sativa L. var. capitata L.). Pol. J. Environ. Stud., 15, 415-441.

Muthaura Ch., Musyimi D.M., Ogur J.A., Okello S.V. 2010. Effective microorganisms and their influence on growth and yield of pigweed (Amaranthus dubians). J. Agric. Biol. Sci., 5, 17-22.

Okoroafor I.B., Okelola E.O., Edeh O.N., Emehute V.C., Onu C.N., Nwaneri T.C., Chinaka G.I., 2013. Effect of organic manure on the growth and yield performance of maize in Ishiagu, Ebonyi State. J Agric.Vet. Sci., 5, 28-31, https://doi.org/10.9790/2380-0542831

Piskier T. 2006. Reaction of spring wheat to the application of bio-stimulators and soil absorbents (in Polish). Journal of Research and Applications in Agricultural Engineering, 51, 136-138.

Polish Soil Classification., 2011. Soil Sci. Ann., 62, 1-193.

Priyadi K., Abdul H., Siagian T.H., Nisa C., Azizah A., Raihani N., Inubushi K., 2005. Effect of soil type, applications of chicken manure and effective microorganisms on corn yield and microbial properties of acidic wetland soils in Indonesia. Soil Sci. Plant Nutr., 51, 689-691, https://doi: 10.1111/j.1747-0765.2005.tb00092.x

Radkowski A., Radkowska I., 2018. Influence of effective microorganisms on the dry matter yield and chemical composition of meadow vegetation. J Elem., 23, 509-520, https://doi: 10.5601/jelem.2017.22.3.1441

Ramakrishnaiah G., Vijaya T., 2013. Influence of VAM fungi, Azotobacter sp. and PSB on soil phosphatase activity and nutrients $(\mathrm{N}, \mathrm{P}, \mathrm{K}, \mathrm{Cu}, \mathrm{Zn}, \mathrm{Fe}$ and $\mathrm{Mn})$ status in the rhizosphere of Stevia rebaudiana (Bert.) plants. Am. J. Plant Sci., 4, 1443-1447, https://doi: 10.4236/ajps.2013.47176

Rapparini F., Peñuelas J., 2014. Mycorrhizal fungi to alleviate drought stress on plant growth. Miransari M. (ed.). Use of microbes for the alleviation of soil stresses. Springer, p. 21-41, https:// doi.org/10.1007/978-1-4614-9466-9 2

Ruiz-Sánchez M., Aroca R., Muñoz Y., Armada E., Polón R., Ruiz-Lozano J.M., 2010. The arbuscular mycorrhizal symbiosis enhances the photosynthetic efficiency and the antioxidative response of rice plants subjected to drought stress. J. Plant Physiol., 167, https://doi: 862-869, 10.1016/j.jplph.2010.01.018

Rutkowska B., Szulc W., Łabętowicz J., 2009. Influence of soil fertilization on concentration of microelements in soil solution of sandy soil. J Elem., 14, 349-355, https://doi: 10.5601/jelem.2009.14.2.15

Siwik-Ziomek A., Lemanowicz J., 2014. The content of carbon, nitrogen, phosphorus and sulphur in soil against the activity of selected hydrolases as affected by crop rotation and fertilisation. Zemdirbyste-Agriculture, 101(4), 367-372, https://doi: 10.13080/z-a.2014.101.046

WRB., 2014. World reference base for soil resources. World Soil Resources Reports, FAO, Rome, 106.

Yamada K., Xu H.L., 2001. Properties and applications of an organic fertilizer inoculated with effective microorganisms. J. Crop Prod., 3(1), 255-268, https://doi: 10.1300/J144v03n01_21

Yang H., Li J., Yang J., Wang H., Zou J., He J., 2014a. Effects of nitrogen application rate and leaf age on the distribution pattern of leaf SPAD readings in the rice canopy. Plos ONE, https://doi 10.1371/journal.pone.0088421

Yang H., Yang J., Lv Y., Junjun H., 2014b. SPAD values and nitrogen nutrition index for the evaluation of rice nitrogen status. Plant Prod. Sci., 17, 81-92, https://doi: 10.1626/pps.17.81 
Yusuf A.A., Mofio B.M., Ahmed A.B., 2007. Proximate and mineral composition of Tamarindus indica Linn. 1753 seeds. Sci. World J., 2, 1-4, , https://doi: 10.4314/swj.v2i1.51699

Zydlik P., Zydlik K., 2008. Impact of biological effective microorganisms (EM) preparations on some physic-chemical properties of soil and the vegetative growth of apple-tree rootstocks. Science Nat Technol., 2, 1-7. 